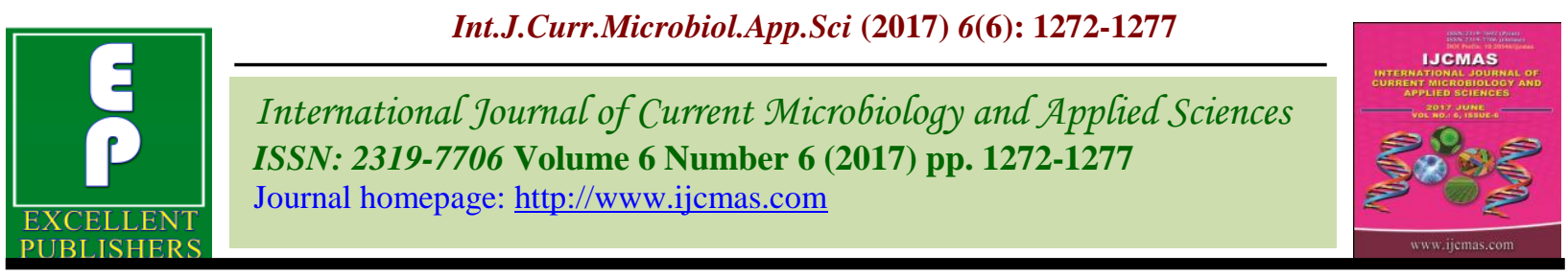

Original Research Article https://doi.org/10.20546/ijcmas.2017.606.149

\title{
Management of Alternaria Leaf Blight of Bottle Gourd in Western Rajasthan, India
}

\author{
S.K. Maheshwari" ${ }^{*}$ B.R. Choudhary, B.D. Sharma and P.L. Saroj \\ ICAR- Central Institute for Arid Horticulture, Bikaner- 334 006, Rajasthan, India \\ *Corresponding author
}

A B S T R A C T

The field trials were conducted during rainy season of 2013 and 2014 for

Keywords

Management, Alternaria leaf

blight, Bottle gourd,

Fungicide, Bio-

agent, Botanical.

Article Info

Accepted:

19 May 2017

Available Online:

10 June 2017 disease management of Alternaria leaf blight in bottle gourd through botanicals, fungicides, bio-agent and their combinations. Among 17 treatments, combined treatment of carbendazim (Seed treatment) @ $0.1 \%+$ mancozeb (Foliar spray)@ 0.25\% + Pseudomonas fluorescens (Foliar spray)@5.0\% + neem leaf extract (Foliar spray) @ 5.0\% was found the most effective with minimum disease incidence of $9.25 \%$, minimum disease severity of $7.07 \%$ and maximum disease control (78.23\%), followed by mancozeb ST @ $0.25 \%$ + carbendazim (FS) @ $0.1 \%$ + Pseudomonas fluorescens CIAH-196 (FS) @ 5.0\% + neem leaf extract (FS) @ 5.0\% having disease incidence $(11.15 \%)$, disease severity $(8.98 \%)$ and disease control $(72.35 \%)$ for management of Alternaria leaf blight of bottle gourd.

\section{Introduction}

Vegetables are the best resource for overcoming micronutrient deficiencies and provide small farmers with much higher income. The worldwide production of vegetables have doubled over the past quarter century and the value of global trade in vegetables now exceeds that of cereals. India is a leading vegetable producing country in the world. Bottle gourd [Lagenaria siceraria (Mol.) Standl] is a commonly grown vegetable crop in India, which is also grown in Ethiopia, Africa, Central America and other warmer regions of the world. It is widely grown on open fields as well as in river beds throughout the year. It is also suitable for cultivation in hot dry areas. The fruits can be used as a vegetable or for making sweets. As a vegetable, it is easily digestible, even by patients (Thamburaj and Singh, 2000). It is gaining importance due to its high yield potential, steady market price throughout the season. The fruits contain $0.2 \%$ protein, $2.9 \%$ carbohydrates, $0.5 \%$ fat and $11 \mathrm{mg}$ of vitamin $\mathrm{C}$ per $100 \mathrm{~g}$ fresh weight (Aykroyd, 1963). It also has wide medicinal properties such as laxative, digestive and to prevent constipation. The crop is attacked by a number of diseases such as Alternaria leaf blight, Cercospora leaf spot, powdery mildew, downy mildew and anthracnose, amongst which Alternaria leaf blight caused by Alternaria cucumerina (E. \& 
E.) Elliot is found to cause serious losses throughout Rajasthan and other states.

Characteristic symptoms first appear as small, circular and light to reddish brown spots, which latter enlarge in a concentric manner. Lesions often coalesce to form larger necrotic areas and in the centre of the spot, olivaceous sporulation occurs. So far, information available on disease management of Alternaria leaf blight of bottle gourd under hot arid condition is scanty. Keeping in view, the present study was undertaken to aware the management of Alternaria leaf blight of bottle gourd in Western Rajasthan.

\section{Materials and Methods}

The field trials were conducted during rainy season of 2013 and 2014 at Pathology Block, ICAR-Central Institute For Arid Horticulture, Bikaner. A bottle gourd variety 'Thar Samridhi' was sown on last week of February of both the years in the field in Randomized Block Design with three replications for management of Alternaria leaf blight of bottle gourd through botanical, fungicides, bio-agent and their different combinations. The spacing maintained between rows was $2.0 \mathrm{~m}$ and between plants $0.50 \mathrm{~m}$. Seventeen treatments such as 01 botanical (neem leaf extract@ 5.0\%), 01 bio-agent (Pseudomonas fluorescens strain CIAH-196@ @.0\%, talc based formulation) and 02 fungicides (carbendazim @ 0.1\% and mancozeb @ $0.25 \%$ ) and their combinations viz., Carbendazim@0.1\% (Seed Treatment, ST) + Mancozeb @ 0.25\% (Foliar spray, FS), Carbendazim (Seed Treatment) + Ps. fluorescens CIAH-196 @ 5.0\% (Foliar spray), Carbendazim ST + Neem leaf extract @ 5.0\% (FS), Mancozeb ST + Carbendazim (FS), Mancozeb $(0.25 \%) \mathrm{ST}+$ Ps. fluorescens CIAH-196 (5\%) FS, Mancozeb (0.25\%) ST + Neem leaf extract (5\%) FS, Carbendazim (ST) + Mancozeb (FS) + Ps. fluorescens
CIAH-196 (5\%) FS, Carbendazim (ST) + Mancozeb (FS) + Neem leaf extract (FS), Carbendazim (ST) + Mancozeb (FS) + Ps. fluorescens (FS) + Neem leaf extract (FS), Mancozeb (ST) + Carbendazim (FS) + Ps. fluorescens CIAH-196 (5\%) FS, Mancozeb $(0.2 \%) \mathrm{ST}+$ Carbendazim (FS) + Neem leaf extract, Mancozeb (0.2\%) ST + Carbendazim (FS) + Ps. fluorescens FS + Neem leaf extract FS and control (without any treatment) were taken for this study. Seed treatment (ST) was done before sowing of bottle gourd crop, followed by only 01 foliar spray (FS) of the combined treatment after appearance of the first disease symptoms. Alternaria leaf blight was observed in the field during both the years.

\section{Isolation and pathogenicity}

Isolation was made in the laboratory. Small bits with typical disease symptoms of infected leaves along with healthy tissues were cut with the help of sterile blade, surface sterilized with $0.1 \%$ mercuric chloride for 30 seconds followed by three washing with sterilized water and plated aseptically in the Petri plates containing 2\% Potato Dextrose Agar (PDA) Medium and incubated at $25 \pm 10 \mathrm{C}$ for seven days. Pathogenicity was established on healthy plants of bottle gourd variety 'Thar Samridhi'. For this study, the plants were raised in plastic pots of $30 \mathrm{~cm}$ diameter filled with sterilized soil and 01 plant per pot was maintained. After 30 days, the plants were artificially inoculated by spraying spore-cum-mycelial suspension, prepared in sterile water. Leaves were used for inoculation purpose. The inoculated plants were covered with polythene bags for 48 hours to provide sufficient humidity for infection. Disease symptoms were produced in the plant leaves. The fungus was re-isolated from the artificially inoculated infected plants and was similar with the original isolate. The recommended packages of practices for this 
crop were adopted. No plant protection measures were taken up during study period during both the years of experimentation. Data on disease incidence and disease severity of Alternaria leaf blight were recorded on maturity stage of the bottle gourd crop. Disease incidence was calculated on the basis of per cent plant infected. Total number of plants and number of infected plants by this disease in each replication of the crop were counted and disease incidence was calculated by following formula:

Number of infected plants Disease incidence $(\%)=$ Total number of plants

Disease severity was recorded on the basis of per cent leaf area affected and it was calculated by using 0-4 disease rating scale (Prasada, et al., 1973).

The per cent data were angular transformed and statistically analyzed by off campus CCSHAU, Hisar (Haryana) OPSTAT statistical analysis software in RBD. Per cent disease control was also calculated by following formula:

Per cent Disease Control $(\mathrm{PDC})=$

$\%$ disease severity in control - $\%$ disease severity in treatment

$\%$ disease severity in control

\section{Results and Discussion}

Data on disease incidence of Alternaria leaf blight are presented in table 1. All the treatments were found superior than control in case of disease incidence. Alternaria leaf blight was found with ranging from 9.25$47.63 \%$ disease incidence. Among 17 treatments, combined treatment of carbendazim (ST) @ 0.1\% + mancozeb (FS) @ $0.25 \%$ + Ps. fluorescens (FS) @ 5.0\% + neem leaf extract (FS) @ 5.0\% was observed the most effective with the minimum disease incidence $(9.25 \%)$ against this disease, followed by mancozeb ST @ $0.25 \%$ + carbendazim (FS) @ 0.1\%+Ps. fluorescens CIAH-196 (FS) @ 5.0\% + neem leaf extract (FS) @ 5.0\% having $11.15 \%$ disease incidence against Alternaria leaf blight of bottle gourd. Both the treatments were statistically at par with each other. Maximum disease incidence $(47.63 \%)$ was found in case of control without any treatment. Data on disease severity of Alternaria leaf blight were also presented of both the years in table 2 . Alternaria leaf blight was found with ranging from $7.07-32.48 \%$ av. disease severity.

Among 17 treatments, the minimum disease severity $(7.07 \%)$ and the maximum disease control $(78.23 \%)$ were found in combined treatment of carbendazim (ST) @ 0.1\%+ mancozeb (FS) @ 0.25\% + Pseudomonas fluorescens (FS) @ 5.0\% + neem leaf extract (FS)@ $0.0 \%$ which was the most efficient, followed by mancozeb ST @ $0.25 \%+$ carbendazim (FS) @ 0.1\%+Ps. fluorescens CIAH-196 (FS) + neem leaf extract (FS) having $8.98 \%$ disease severity and disease control $(72.35 \%)$ for management of Alternaria leaf blight of this crop. Both the treatments were statistically at par with each other.

The next best treatments were carbendazim (ST)@0.1\% + mancozeb (FS) @ 0.25\% + Ps. fluorescens CIAH-196 (5\%) FS as well as carbendazim (ST) + mancozeb (FS) + neem leaf extract (FS) with disease severity of $10.80 \%$ and $11.67 \%$ as well as disease control $(66.75 \%)$ and $(64.07 \%)$, respectively which were statistically at par with each other. Maximum disease severity $(32.48 \%)$ was found in control without any treatment, followed by Pseudomonas fluorescens CIAH196 ST @ 5.0\% having 27.85\% disease severity. 
Table.1 Effect of fungicides, bio-agent, botanical and their combinations on disease incidence of Alternaria leaf blight of bottle gourd

\begin{tabular}{|c|c|c|c|c|}
\hline $\begin{array}{l}\text { S. } \\
\text { No. }\end{array}$ & Name of treatments with dose & $\begin{array}{l}\text { \% disease } \\
\text { incidence } \\
\text { (2013) }\end{array}$ & $\begin{array}{l}\text { \% disease } \\
\text { incidence } \\
\text { (2014) }\end{array}$ & $\begin{array}{l}\text { Mean }(2013 \& \\
\text { 2014) }\end{array}$ \\
\hline 1. & Carbendazim (0.1\%) ST & $25.0(29.96)^{*}$ & $30.0(33.18)^{*}$ & $27.50(31.61)^{*}$ \\
\hline 2. & Mancozeb $(0.25 \%)$ ST & $30.0(33.15)$ & $33.33(35.19)$ & $31.66(34.21)$ \\
\hline 3. & $\begin{array}{l}\text { Pseudomonas fluorescens CIAH- } \\
196(5 \%) \text { ST }\end{array}$ & $33.33(35.19)$ & $35.50(36.54)$ & $34.41(35.87)$ \\
\hline 4 & Neem leaf extract (5\%) ST & $30.0(33.18)$ & $33.33(35.15)$ & $31.66(34.18)$ \\
\hline 5 & $\begin{array}{l}\text { Carbendazim (ST) }+ \text { Mancozeb } \\
(\mathrm{FS})\end{array}$ & $20.0(26.34)$ & $25.0(29.93)$ & $22.50(28.19)$ \\
\hline 6 & $\begin{array}{l}\text { Carbendazim } \quad(\mathrm{ST}) \\
\text { fluorescens CIAH-196 FS }\end{array}+P s$. & $20.0(26.47)$ & $25.0(29.87)$ & $22.50(28.26)$ \\
\hline 7 & $\begin{array}{l}\text { Carbendazim ST }+ \text { Neem leaf } \\
\text { extract }\end{array}$ & $25.0(29.93)$ & $30.50(33.42)$ & $27.75(31.71)$ \\
\hline 8 & Mancozeb ST + Carbendazim (FS) & $20.0(26.45)$ & $25.0(29.80)$ & $22.50(27.95)$ \\
\hline 9 & $\begin{array}{l}\text { Mancozeb }(0.25 \%) \\
\text { fluorescens } \\
\text { CIAH-196 (5\%) FS }\end{array}$ & $25.0(29.93)$ & $28.60(32.25)$ & $26.80(31.12)$ \\
\hline 10 & $\begin{array}{l}\text { Mancozeb }(0.25 \%) \text { ST + Neem leaf } \\
\text { extract }(5 \%) \text { FS }\end{array}$ & $20.0(26.47)$ & $25.0(29.91)$ & $22.50(28.30)$ \\
\hline 11. & $\begin{array}{l}\text { Carbendazim (ST) + Mancozeb } \\
(\mathrm{FS})+\text { Ps. fluorescens } \text { CIAH-196 } \\
(5 \%) \mathrm{FS}\end{array}$ & $12.50(20.63)$ & $15.65(23.22)$ & $14.07(23.35)$ \\
\hline 12. & $\begin{array}{l}\text { Carbendazim (ST) + Mancozeb } \\
(\mathrm{FS})+\text { Neem leaf extract }(\mathrm{FS})\end{array}$ & $15.0(22.62)$ & $20.0(26.34)$ & $17.5(24.57)$ \\
\hline 13 & $\begin{array}{l}\text { Carbendazim (ST) + Mancozeb } \\
(\mathrm{FS})+\text { Ps. fluorescens }(\mathrm{FS})+\text { Neem } \\
\text { leaf extract }(\mathrm{FS})\end{array}$ & $8.50(16.65)$ & $10.0(18.16)$ & $9.25(17.53)$ \\
\hline 14 & $\begin{array}{l}\text { Mancozeb }(\mathrm{ST})+\text { Carbendazim } \\
(\mathrm{FS})+\text { Ps. fluorescens CIAH-196 } \\
(5 \%) \mathrm{FS}\end{array}$ & $16.67(24.03)$ & $20.0(26.34)$ & $18.33(25.21)$ \\
\hline 15 & $\begin{array}{llcr}\text { Mancozeb } & (0.2 \%) & \text { ST } & + \\
\text { Carbendazim } & (\text { FS })+ & \text { Neem } & \text { leaf } \\
\text { extract } & & & \end{array}$ & $25.0(29.87)$ & $26.50(30.88)$ & $25.75(30.39)$ \\
\hline 16. & $\begin{array}{l}\text { Mancozeb } \quad(0.2 \%) \quad \text { ST }+ \\
\text { Carbendazim }(F S)+\text { Ps. fluorescens } \\
\text { CIAH-196 FS + Neem leaf extract } \\
\text { FS }\end{array}$ & $10.0(18.34)$ & $12.30(20.24)$ & $11.15(19.34)$ \\
\hline 17. & Control & $45.25(42.25)$ & $50.0(44.98)$ & $47.63(43.61)$ \\
\hline & CD & 5.326 & 6.54 & 5.21 \\
\hline
\end{tabular}

*Figures in parenthesis are angular transformed value $\mathrm{ST}=$ Seed treatment, $\mathrm{FS}=$ Foliar treatment 
Table.2 Effect of fungicides, bio-agent, botanical and their combinations on disease severity of Alternaria leaf blight of bottle gourd

\begin{tabular}{|c|c|c|c|c|c|}
\hline $\begin{array}{l}\text { S. } \\
\text { No. }\end{array}$ & $\begin{array}{l}\text { Name of treatments with } \\
\text { dose }\end{array}$ & $\begin{array}{l}\text { Disease } \\
\text { severity }(\%) \\
\text { during } 2013 \\
\end{array}$ & $\begin{array}{l}\text { Disease } \\
\text { severity }(\%) \\
\text { during } 2014 \\
\end{array}$ & $\begin{array}{l}\text { Mean } \\
(2013 \& \\
2014)\end{array}$ & $\begin{array}{l}\text { Per cent } \\
\text { disease } \\
\text { control }\end{array}$ \\
\hline 1. & Carbendazim $(0.1 \%) \mathrm{ST}$ & $22.10 *(28.04)$ & $24.70 *(29.77)$ & $23.40(26.49)^{*}$ & 27.95 \\
\hline 2. & Mancozeb $(0.25 \%)$ ST & $23.15(28.76)$ & $25.40(30.25)$ & $24.27(29.51)$ & 25.27 \\
\hline 3. & $\begin{array}{l}\text { Pseudomonas fluorescens } \\
\text { CIAH-196 (5\%) ST }\end{array}$ & $26.50(30.98)$ & $29.20(32.73)$ & $27.85(31.42)$ & 14.25 \\
\hline 4 & Neem leaf extract (5\%) ST & $25.15(30.10)$ & $26.80(30.93)$ & $25.97(30.97)$ & 20.04 \\
\hline 5 & $\begin{array}{l}\text { Carbendazim (ST) + } \\
\text { Mancozeb (FS) }\end{array}$ & $17.20(24.50)$ & $18.50(25.30)$ & $17.85(24.89)$ & 45.04 \\
\hline 6 & $\begin{array}{l}\text { Carbendazim (ST) + Ps. } \\
\text { fluorescens CIAH-196 FS }\end{array}$ & $18.90(25.77)$ & $19.50(26.15)$ & $19.20(25.96)$ & 40.88 \\
\hline 7 & $\begin{array}{l}\text { Carbendazim ST + Neem leaf } \\
\text { extract }\end{array}$ & $19.50(26.20)$ & $21.70(27.69)$ & $20.60(26.95)$ & 36.57 \\
\hline 8 & $\begin{array}{l}\text { Mancozeb ST + Carbendazim } \\
\text { (FS) }\end{array}$ & $18.50(25.47)$ & $20.60(26.92)$ & $19.55(26.22)$ & 39.81 \\
\hline 9 & $\begin{array}{l}\text { Mancozeb }(0.25 \%) \mathrm{ST}+P s . \\
\text { fluorescens CIAH-196 }(5 \%) \\
\text { FS }\end{array}$ & $20.15(26.67)$ & $22.50(28.30)$ & $21.33(27.49)$ & 34.33 \\
\hline 10 & $\begin{array}{l}\text { Mancozeb }(0.25 \%) \text { ST }+ \text { Neem } \\
\text { leaf extract }(5 \%) \mathrm{FS}\end{array}$ & $21.50(27.62)$ & $20.30(26.76)$ & $20.90(27.18)$ & 35.65 \\
\hline 11. & $\begin{array}{l}\text { Carbendazim (ST) + } \\
\text { Mancozeb (FS) + Ps. } \\
\text { fluorescens CIAH-196 (5\%) } \\
\text { FS }\end{array}$ & $9.90(18.34)$ & $11.70(19.78)$ & $10.80(19.07)$ & 66.75 \\
\hline 12. & $\begin{array}{l}\text { Carbendazim (ST) + } \\
\text { Mancozeb (FS) + Neem leaf } \\
\text { extract (FS) }\end{array}$ & $11.25(19.60)$ & $12.10(20.28)$ & $11.67(19.94)$ & 64.07 \\
\hline 13 & $\begin{array}{l}\text { Carbendazim (ST) + } \\
\text { Mancozeb (FS) + Ps. } \\
\text { fluorescens (FS) + Neem leaf } \\
\text { extract (FS) }\end{array}$ & $6.50(14.77)$ & $7.65(15.96)$ & $7.07(15.36)$ & 78.23 \\
\hline 14 & $\begin{array}{l}\text { Mancozeb }(\mathrm{ST})+ \\
\text { Carbendazim }(\mathrm{FS})+P s . \\
\text { fluorescens CIAH-196 }(5 \%) \\
\text { FS }\end{array}$ & $13.75(21.76)$ & $16.20(23.65)$ & $14.97(21.14)$ & 53.91 \\
\hline 15 & $\begin{array}{l}\text { Mancozeb }(0.2 \%) \mathrm{ST}+ \\
\text { Carbendazim (FS) }+ \text { Neem } \\
\text { leaf extract }\end{array}$ & $15.40(23.10)$ & $18.60(25.41)$ & $17.0(24.33)$ & 47.66 \\
\hline 16. & $\begin{array}{l}\text { Mancozeb }(0.2 \%) \mathrm{ST}+ \\
\text { Carbendazim (FS) }+P s . \\
\text { fluorescens CIAH-196 FS + } \\
\text { Neem leaf extract FS }\end{array}$ & 8.25 (16.69) & $9.70(18.13)$ & $8.98(17.42)$ & 72.35 \\
\hline \multirow[t]{2}{*}{17.} & Control & $28.75(32.42)$ & $36.20(36.96)$ & $32.48(34.72)$ & - \\
\hline & CD & 3.24 & 3.59 & 3.10 & \\
\hline
\end{tabular}

*Figures in parenthesis are angular transformed value $\mathrm{ST}=$ Seed treatment, $\mathrm{FS}=$ Foliar treatment 
The best control of Alternaria leaf spot disease of bottle gourd was obtained by spraying of indofil M-45 followed by chlorothalonil and ridomil (Katiyar et al., 2001). Raja and Reddy (2008) reported that ziram $(0.2 \%)$, followed by mancozeb $(0.2 \%)$ was found very effective against leaf spot of brinjal caused by Alternaria tenuissima. Dushyant et al., (2014) found in the field that carbendazim + mancozeb was the most effective treatment for management of early blight of tomato (Alternaria solani) with the minimum disease severity of $8.2 \%$, followed by mancozeb and iprodione + carbendazim with disease severity of $11.4 \%$ and $15.2 \%$, respectively.

From the above studies, it is concluded that Alternaria is a destructive pathogen causing a widespread destruction in vegetables. But it becomes easier to control this cosmopolitan fungus. Keeping in mind, it is advisable to the growers to manage Alternaria leaf blight disease of bottle gourd by adopting management measures of combine treatments (carbendazim (Seed treatment) @ 0.1\% + mancozeb (Foliar spray) @ 0.25\% + Pseudomonas fluorescens (Foliar spray) @ $5.0 \%$ + neem leaf extract (Foliar spray) @ $5.0 \%)$.

This disease may attain an alarming status and may wreak havoc in bottle gourd growing areas if not taken care well in time. Therefore, it is need of the hour to know effective management strategy against this dreaded disease of the crop.

\section{References}

Aykroyd, W.R. 1963. The Nutritive value of Indian Foods and Planning of satisfactory diet. ICMR Special Rep. Series No. 42.

Dushyant, Khatri, N.K., Prasad, J. and Maheshwari, S.K. 2014. Efficacy of fungicides against early blight of tomato caused by Alternaria solani. Annals Plant Protect. Sci., 22(1): 148-151.

Katiyar, A., Kant, S., Chauhan, S.S. and Singh, A. 2001. Chemical control of Alternaria leaf spot of bottle gourd. Annals Plant Protect. Sci., 9(2): 339341.

Prasada, R., Khandelwal, G.L. and Jain, J.P. 1973. Epidemiology, forecasting and control of Alternaria blight of cucurbits. Proc. Indian National Sci. Acad., 37: 301-308.

Raja, P. and Reddy, A.V.R. 2008. Efficacy of fungicides on leaf spot of eggplant caused by Alternaria tenuissima. Ann. Pl. Protec. Sci., 16(1): 237- 239

Thamburaj, S. and Singh, N. 2000. Textbook of Vegetables, Tuber crops and Spices. Published by DIPA, ICAR, and New Delhi. 469 p.

\section{How to cite this article:}

Maheshwari, S.K., B.R. Choudhary, B.D. Sharma and Saroj, P.L. 2017. Management of Alternaria Leaf Blight of Bottle Gourd in Western Rajasthan, India. Int.J.Curr.Microbiol.App.Sci. 6(6): 1272-1277. doi: https://doi.org/10.20546/ijcmas.2017.606.149 